\title{
ARTIFICIAL NEURAL NETWORKS AS A NEW TOOL FOR ASSESSING AND MONITORING WOOD MOISTURE CONTENT ${ }^{1}$
}

Antônio José Vinha Zanuncio ${ }^{2 *}$, Amélia Guimarães Carvalho ${ }^{2}$, Liniker Fernandes da Silva ${ }^{2}$, Angélica de Cássia Oliveira Carneiro ${ }^{3}$ and Jorge Luiz Colodette ${ }^{3}$

\footnotetext{
${ }^{1}$ Received on 05.12.2014 accepted for publication on 07.03.2016.

${ }^{2}$ Universidade Federal de Viçosa, Programa de Pós-Graduação em Ciência Florestal, Viçosa, MG - Brasil. E-mail: $<$ ajvzanuncio@yahoo.com.br>,<ameliagcarvalho@gmail.com> and $<$ linikerfs@gmail.com>

${ }^{3}$ Universidade Federal de Viçosa, Departamento de Engenharia Florestal, Viçosa, MG - Brasil. E-mail: <cassiacarneiro1@gmail.com> and <colodett@ufv.br>.

*Corresponding author.
}

\begin{abstract}
Drying of wood is necessary for its use and moisture control is important during this process. The aim of this study was to use artificial neural networks to evaluate and monitor the wood moisture content during drying. Wood samples of $2 \times 2 \times 4 \mathrm{~cm}$ were taken at $1.3 \mathrm{~m}$ above the ground, outside of radial direction, from seven 2 -year-old materials and three 7-year-old materials. These samples were saturated and drying was evaluated until the equilibrium moisture content, then, the artificial neural networks were created. The materials with higher initial moisture reached equilibrium moisture content faster due to its higher drying rate. The basic density of all wood materials was inversely proportional at the beginning and directly proportional to the moisture at the end of drying. All artificial neural networks used in this work showed high accuracy to estimate the moisture, however, the neural network based on the basic density and drying days was the best. Therefore, artificial neural networks can be used to control the moisture content of wood during drying.
\end{abstract}

Keywords: Eucalyptus urophylla $\times$ Eucalyptus grandis; Drying; Modeling.

\section{REDES NEURAIS ARTIFICIAIS COMO NOVA FERRAMENTA PARA AVALIAÇÃO E MONITORAMENTO DA UMIDADE DA MADEIRA}

\begin{abstract}
RESUMO - A secagem da madeira é necessária para sua utilização e o controle da umidade é fundamental durante este processo. O objetivo deste trabalho foi utilizar redes neurais artificiais para avaliar e monitorar a umidade da madeira durante a secagem. Amostras de $2 \times 2 \times 4 \mathrm{~cm}$ foram retiradas a 1,3 metros acima do solo na parte externa no sentido radial de sete materiais de dois anos e três de sete anos de Eucalyptus urophylla x Eucalyptus grandis. Essas amostras foram saturadas e sua secagem avaliada até a umidade de equilibrio, logo após, foram criadas as redes neurais artificiais. Os materiais com maior umidade inicial atingiram a umidade de equilíbrio mais rápido, devido a maior taxa de secagem. A densidade básica da madeira de todos os materiais foi inversamente proporcional no inicio e diretamente proporcional à umidade no final da secagem. A rede neural artificial baseada na densidade básica e nos dias de secagem apresentou alta precisão para avaliar e monitorar a umidade da madeira. Portanto, as redes neurais artificiais podem ser utilizadas para controle da umidade da madeira durante a secagem.
\end{abstract}

Palavras-chave: Eucalyptus urophylla $\times$ Eucalyptus grandis; Modelagem; Secagem. 


\section{INTRODUCTION}

Forestry sector represents $1,1 \%$ of the gross national product in Brazil (IBA, 2014), and the biomass produced can be used for cellulose pulp (PIRRALHO et al., 2014), energy (SOARES et al., 2014; ZANUNCIO et al., 2014a), panels (CARVALHO et al., 2014a; CARVALHO et al., 2014b), and lumber production (KWON et al., 2014; SALCA; HIZIROGLU, 2014). In all these sectors, wood drying is necessary.

The drying behavior differs over time due to interactions between water and wood. Freshly cut timber has large amounts of water called free water in the vessels and lumen fibers connected to the wood by weak capillary connections (ENGELUND et al 2013). The wood reaches the fiber saturation point between $20 \%$ and $35 \%$ (SIAU, 1971), and then loses adsorption water adsorption until the equilibrium moisture (KOLLMANN; CÔTÉ, 1968). The relation between wood and adsorption water adsorption affects its physical (ZANUNCIO et al., 2014a) and mechanical properties (MASSETEAU et al, 2014). Finally, the water constitution of wood is removed only after its complete degradation (SKAAR, 1972).

Wood moisture during drying can be monitored by regression models (REZENDE et al., 2010; ZANUNCIO et al 2013a). However, artificial neural networks, used in resistance of wood materials (TIRYAKI; AYDIN, 2014a, b), may increase the accuracy of these models. This technique uses, in simplified form, neural networks of biological brains with computational processes, including simple processing units connected to perform a function or task (KOVÁCS, 2002).

The objective of this study was to produce models with artificial neural networks to evaluate and predict wood moisture content during drying.

\section{MATERIALAND METHODS}

Seven materials with 2-year-old (clones A, B, D, $\mathrm{E}, \mathrm{F}, \mathrm{G}$ ) and three with 7-year-old clones (clones C, $\mathrm{I}, \mathrm{J})$ of Eucalyptus urophylla $\times$ Eucalyptus grandis were used. Three trees were harvested per clone. These trees were cut and $40 \mathrm{~cm} \operatorname{logs}$ were taken from $1.3 \mathrm{~m}$ above the ground to make five $2 \times 2 \times 4 \mathrm{~cm}$ samples per tree and 15 samples per clone (Figure 1).

The samples were saturated until constant weight, conditioned in a climatic chamber at $23^{\circ} \mathrm{C}$ with $50 \%$

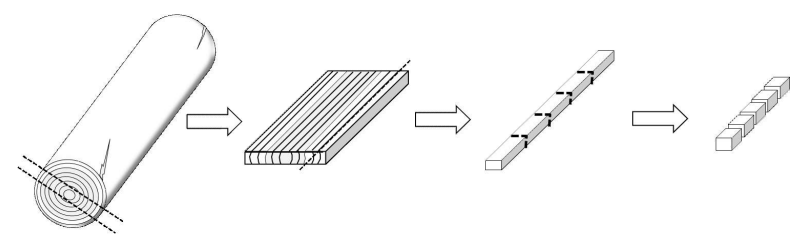

Figure 1- Removal of the wood samples from ten Eucalyptus urophylla $\times$ Eucalyptus grandis clones for saturation and drying evaluation

Figura 1-Retirada dos corpos de prova dos clones de Eucalyptus urophylla $\times$ Eucalyptus grandis para saturação e posterior secagem

relative humidity, and weighed twice a day in the first 7 days and once a day in the 8 days to determine water losses. The density and humidity of the specimens were determined according to NBR 11941: 2003 (ABNT, 2003).

A curve of moisture loss as a function of days of drying was obtained per clone. The relationship between basic density and wood moisture after saturation and $1,1.5,7$, and 15 days of drying was analyzed by Pearson correlation coefficient.

The artificial neural networks to monitor and predict moisture content were developed based on the genetic material and basic density with days of drying.

\section{RESULTS}

\subsection{Wood Drying}

The moisture content in the saturated wood and the drying rate until equilibrium moisture differed between the materials in the same environmental conditions (Figure 2), showing the influence of raw material on the drying process.

\subsection{Relationship between basic density and moisture}

The basic density of the samples, when analyzed separately, showed a relationship with wood moisture content during the study period, being inversely proportional at the beginning and directly proportional to the moisture at the end of drying (Figure 3 ).

\subsection{Accuracy of artificial neural networks}

The wood moisture was modeled with the variables Moisture $=\mathrm{f}($ density, day $)$, artificial neural network $A$, and Moisture $=f($ clone, day $)$, artificial neural network B. The Scaled Conjugate Gradient was the algorithm 

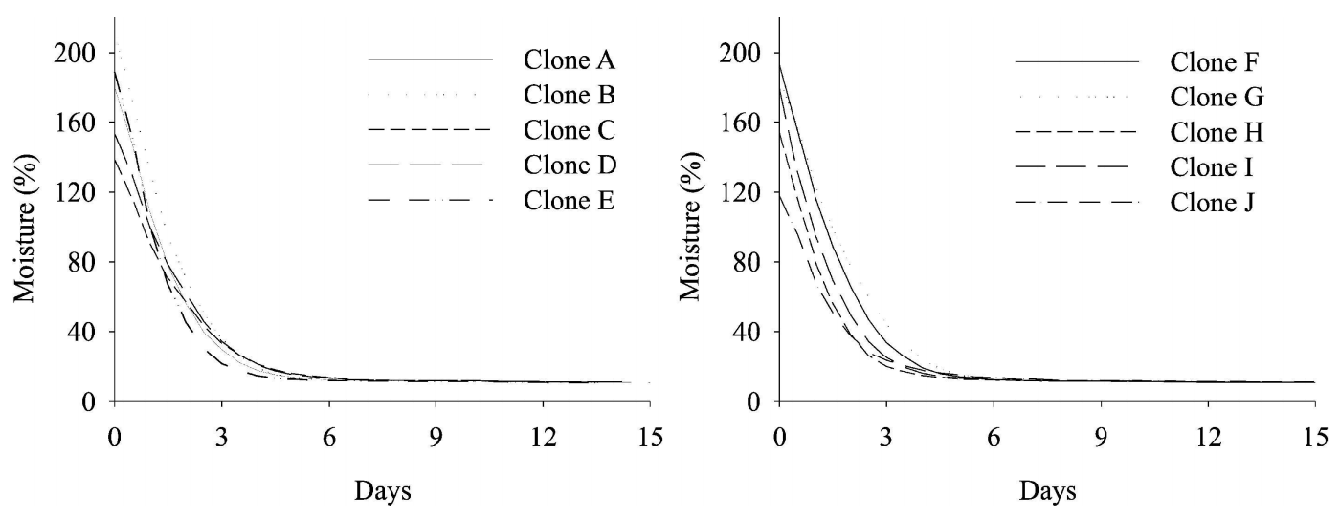

Figure 2 - Wood moisture in ten Eucalyptus urophylla x Eucalyptus grandis clones during drying period.

Figura 2 - Umidade da madeira de dez clones de Eucalyptus urophylla x Eucalyptus grandis em função dos dias de secagem.
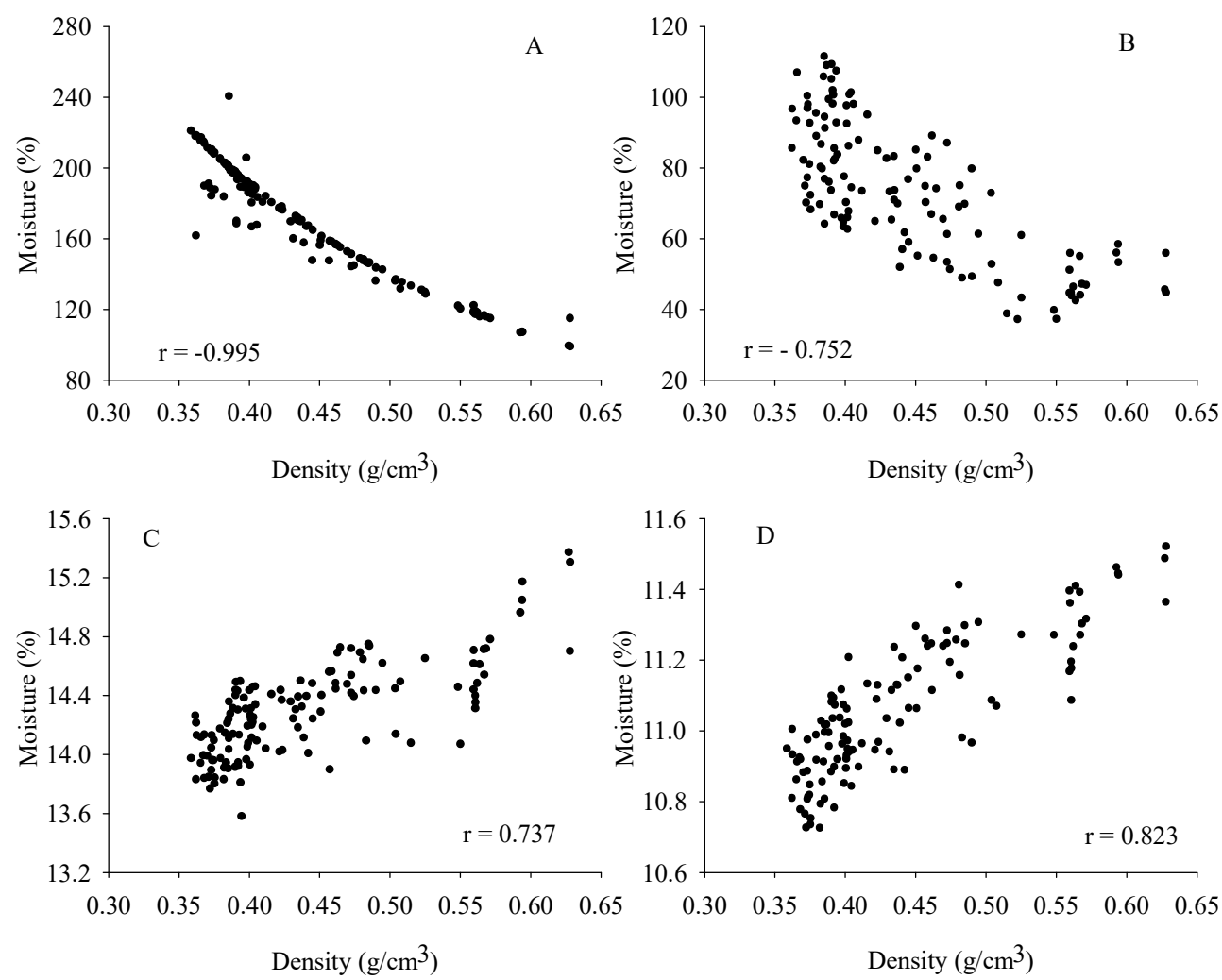

Figure 3 - Relationship between basic density and moisture of Eucalyptus urophylla $\times$ Eucalyptus grandis wood, saturated (A) and after 1.5 (B); 7 (C) and 15 (D) days of drying.

Figura 3 - Relação entre a densidade básica e a umidade na madeira saturada (A) e após 1,5 (B); 7(C) e 15 (D) dias de secagem.

that generated the best results and the Multilayer Perceptron (MLP) type was the best architecture. The selected networks showed a correlation coefficient of $99.06 \%$ and $98.83 \%$ and root mean square error of less than $20 \%$ (Table 1 ).

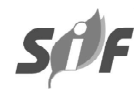

The artificial neural network selected showed desirable relative frequency of errors, with normal distribution. $81.6 \%$ of the data in artificial neural network $A$ and $76.6 \%$ in artificial neural network $\mathrm{B}$ showed relative frequency error between $-10 \%$

Revista Árvore, Viçosa-MG, v.40, n.3, p.543-549, 2016 
Table 1 - Artificial Neural Network (ANN) architecture (Archit.), input variables (variables), generalized correlation coefficient (Coef) and root mean square error (Root Square) of selected neural networks to estimate the wood moisture.

Tabela 1 - Rede neural artificial (ANN), arquitetura (Arquit.), variáveis de entrada (Variables), coeficiente de correlação generalizado (Coef.) e raiz quadrada do erro médio (Root Square) das redes neurais selecionadas para estimar a umidade da madeira.

\begin{tabular}{ccccc}
\hline ANN & Archit. & Variables & Coef. & Root Square \\
\hline A & $2-4-1$ & Density, Day & 99,06 & $17,47 \%$ \\
B & $11-6-1$ & Clone, Day & 98,83 & $19,74 \%$ \\
\hline
\end{tabular}

and $10 \%$, this values are acceptable in wood moisture control (ZANUNCIO et al., 2014b; 2015)..

\section{DISCUSSION}

\subsection{Wood Drying}

The moisture loss was higher for all the materials in the first drying periods, similar to that reported for
E. urophylla logs (REZENDE et al., 2010; ZANUNCIO et al., 2013b) and Pinus radiata and Eucalyptus dunnii lumber (ANANIAS et al., 2013; SEVERO et al., 2013). At this stage, the timber has higher volume of free water that weakly interacts with wood and is easily removed, thus increasing the drying rate (ENGELUND et al., 2013). At the end of drying, the drying rate of wood decreases due to the higher energy required to remove the water (SKAAR, 1972).
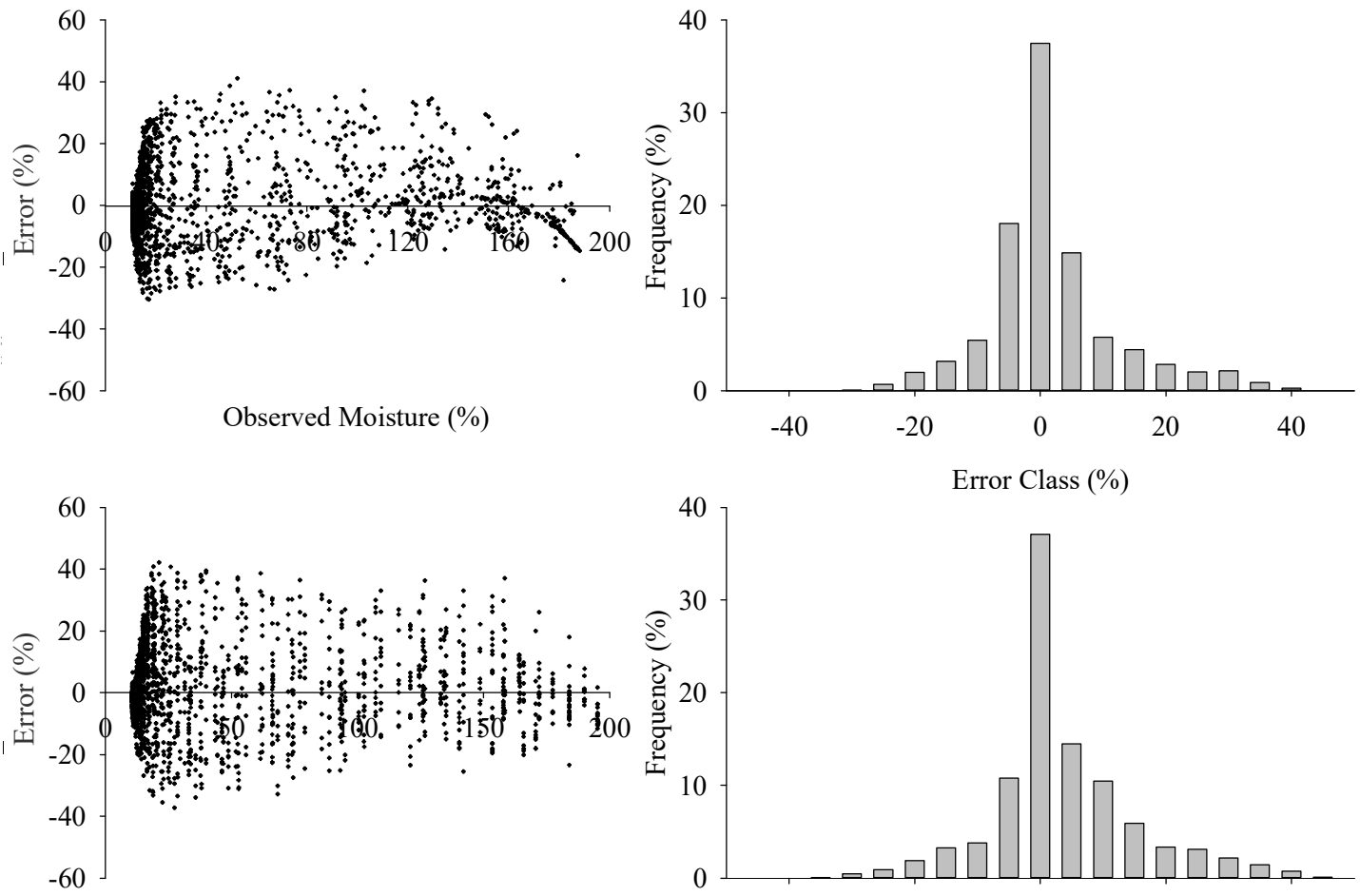

Observed Moisture (\%)

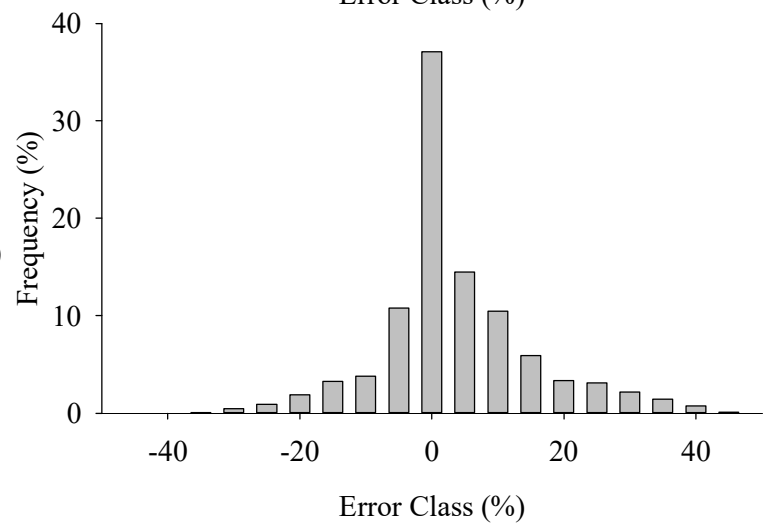

Figure 4 - Dispersion and frequency of errors in neural networks generalized to estimate the moisture content of Eucalyptus urophylla $\times$ Eucalyptus grandis wood during the drying period. (A) Neural network based on the basic density and days drying; (B) Neural network based in clone and days drying.

Figura 4-Dispersão e frequência de erros nas redes neurais generalizadas para estimar a umidade em Eucalyptus urophylla $\times$ Eucalyptus grandis, durante o período de secagem. (A) rede neural com base na densidade básica e dias de secagem; (B) rede neural baseada no clone e dias de secagem.

Revista Árvore, Viçosa-MG, v.40, n.3, p.543-549, 2016 
The moisture content was the highest in clones $\mathrm{B}$ and $\mathrm{F}$ and lowest in clones $\mathrm{C}$ and $\mathrm{J}$ after being saturated. However, the drying rate of the first clones was higher during the study period and, after 4.5 days of drying, these materials showed lower moisture than $\mathrm{C}$ and $\mathrm{J}$ clones, a trend that was noted until the end of drying. The clones $\mathrm{C}$ and $\mathrm{J}$ were 7 years old, and an increase in age results in the production of fibers with greater length and cell wall fraction (PILLAI et al., 2013; MACEDO et al., 2014). This higher cell wall volume reduces wood moisture when saturated and prevents water flow, reducing the drying rate (KOLLMANN; CÔTÉ, 1968). Thus, an understanding of the drying behavior is important to choose artificial neural network models with higher accuracy.

\subsection{Relationship between basic density and moisture}

The basic density of the materials tested, ranged from 0.359 to $0.628 \mathrm{~g} / \mathrm{cm}^{3}$, similar to that of E. urophylla and Eucalyptus paniculata, between 0.390 and 0.653 $\mathrm{g} / \mathrm{cm}^{3}$ (SETTE JR et al., 2012; ZANUNCIO et al., 2014b; FERNANDES et al., 2014).

The relationship between the basic density and wood moisture after saturation showed a Pearson correlation coefficient of 0.995 , which can be explained by the fact that materials with lower basic density have higher void volume, such as lumen fibers, vessel elements, and other cavities filled with water during the saturation period, which increases the wood moisture content (ENGELUND et al., 2013; SIAU, 1971). Moreover, these spaces facilitate the release of water (KOLLMANN; CÔTÉ, 1968). After 1.5 days of drying, the relationship between the basic density and moisture was inversely proportional, but with a lower ratio between these parameters. At seven days of drying, a Pearson correlation coefficient of 0.737 showed that materials with lower basic density had lower moisture due to their higher drying rate, and this trend continued until the end of drying.

After 15 days of drying, the wood moisture stabilized, indicating that the samples reached the equilibrium moisture content, but its value differed with the wood density. High Pearson correlation coefficients between basic density and moisture during drying are essential to produce artificial neural network models with high accuracy.

\subsection{Accuracy of artificial neural networks}

The correlation coefficients with the neural networks were higher than those obtained with the regression models to estimate the moisture of E. urophylla during drying, ranged from $82.6 \%$ to $98.7 \%$ (REZENDE et al., 2010; ZANUNCIO et al., 2013a), demonstrating the efficiency of the artificial neural network in monitoring and predicting the wood moisture content.

The artificial neural network A, based on the wood basic density and days of drying, showed greater accuracy in estimate moisture. Furthermore, the use of basic density as a parameter in the neural network architecture enables its application on a larger number of materials, broadening its utilization. Conversely, the artificial neural network $\mathrm{B}$, based in clone and days of drying, can be used only for the clones employed in the present study. The errors in the estimates presented in both neural networks are due to the heterogeneous behavior of moisture losses during drying and factors not assessed, as wood anatomy. Artificial neural networks are efficient in predicting the wood moisture content and this methodology can be applied to monitor and control moisture in logs and lumber.

\section{CONCLUSION}

The drying behavior of E. urophylla $\times$ E. grandis clones was heterogeneous, with clones with higher humidity when saturated reaching the equilibrium moisture faster due to their higher drying rate. The wood basic density was inversely proportional to moisture in the initial drying periods and directly proportional to moisture during the final stages of drying. All models of artificial neural networks were effective, however, the artificial neural networks using basic density and days of drying to monitor wood moisture showed high precision.

\section{ACKNOWLEDGEMENTS}

To "Conselho Nacional de Desenvolvimento Científico e Tecnológico (CNPq)", "Coordenação de Aperfeiçoamento de Pessoal de Nível Superior (CAPES)" and "Fundação de Amparo à Pesquisa do Estado de Minas Gerais (FAPEMIG)" for financial support. Global Edico Services of India which corrected the English language used in this manuscript.

\section{REFERENCES}

ANANIAS, S.A.; MENA, M.; ELUSTONDO, D.M.; DIAZ-VAZ, J.E.; VALENZUELA, L.;

Revista Árvore, Viçosa-MG, v.40, n.3, p.543-549, 2016

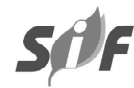


SALINAS, C. Testing new in-kiln meter for monitoring lumber moisture content during drying. Drying Technology: An International Journal, v.31, n.3, p.277-281, 2013.

\section{ASSOCIAÇÃO BRASILEIRA DE NORMAS} TÉCNICAS - ABNT. NBR 11941: madeira: determinação da densidade básica. Rio de Janeiro: 2003. 6p.

CARVALHO, A.G.; MORI, F.A.; MENDES, R.F.; ZANUNCIO, A.J.V.; DA SILVA, M.G.; MENDES, L.M.; MORI, C.L.S.O. Use of tannin adhesive from Stryphnodendron adstringens (Mart.) Coville in the production of OSB panels. European Journal of Wood and Wood Products, v.72, n.4, p.425-432, 2014 a.

CARVALHO, A.G.; ZANUNCIO, A.J.V.; MORI, F.A.; MENDES, R.F.; DA SILVA, M.G.; MENDES, L.M. Tannin adhesive from Stryphnodendron adstringens (MART.) COVILLE in plywood panels. Revista Árvore, v38, n.1, p.195-202, 2014b.

ENGELUND, E.T.; THYGESEN, L.G.; SVENSSON, S.; HILL, C.A.S. A critical discussion of the physics of wood-water interactions. Wood Science and Technology, v.47, n.1, p.141$161,2013$.

FERNANDES, B.V.; ZANUNCIO, A.J.V.; FURTADO, E.L.; ANDRADE, H.L. Damage and loss due to Ceratocystis fimbriata in Eucalyptus wood for charcoal production. BioResources, v.9, n.3, p.5473-5479, 2014.

NDÚSTRIA BRASILEIRA DE ÁRVORES - IBA. Anuário Estatístico da IBA 2014. Ano Base 2013, 21 pp, 2014. Disponível em http:// www.bracelpa.org.br/shared/2014.09.01.bookletpt.pdf

KOVÁCS, Z.L. Redes neurais artificiais: Fundamentos e aplicações. $3^{\text {a }}$.ed. São Paulo: .Livraria da Física, 2002. 174p.

KOLlmanN, F.F.P.; CÔTÉ, W.A. Principles of wood science and technology: solid wood. New York: Springer, 1968. 592p.

KWON, J.H.; SHIN, R.; AYRILMIS, N.; HAN, T.H. Properties of solid wood and laminated wood

Revista Árvore, Viçosa-MG, v.40, n.3, p.543-549, 2016 lumber manufactured by cold pressing and heat treatment. Materials and Design, v.62, p.375-381, 2014.

MACEDO, T.M.; BARROS, C.F.; LIMA, H.C.; COSTA, C.G. Wood anatomy of seven species of Tachigali (Caesalpinioideae-Leguminosae). Iawa Journal, v.35, n.1, p.19-30, 2014.

MASSETEAU, B.; MICHAUD, F.; IRLE, M.; ROYA, A.; ALISE, G. An evaluation of the effects of moisture content on the modulus of elasticity of a unidirectional flax fiber composite.

Composites: Part A, v.60, n.2, p.32-37, 2014.

PILLAI, P.H.C.; PANDALAI, R.C.;

DHAMODARAN, T.K.; SANKARAN, K.V. Effect of silvicultural practices on fibre properties of Eucalyptus wood from short-rotation plantations. New Forests, v.44, v.4, p.521-532, 2013.

PIRRALHO, M.; FLORES, D.; SOUSA, V.B.; QUILHÓ, T.; KNAPICA, S.; PEREIRA, H. Evaluation on paper making potential of nine Eucalyptus species based on wood anatomical features. Industrial Crops and Products, v.54, n.2, p.327-334, 2014.

REZENDE, R.N.; LIMA, J.T.; DA SILVA, J.R.M.; NAPOLI, A.; ANDRADE, H.B.; FARIA, A.L.R. Air drying of logs from Eucalyptus urophylla clone for carbonization use. Cerne, v.16, n.4, p.565572,2010

SALCA, E.A.; HIZIROGLU, S. Evaluation of hardness and surface quality of different wood species as function of heat treatment. Materials and Design, v.62, n.4, p.416-423, 2014.

SETTE, C.R.; DE OLIVEIRA, I.R.; TOMAZELLO FILHO, M.; YAMAJI, F.M.; LACLAU, J.P. Efeito da idade e posição de amostragem na densidade e características anatômicas da madeira de Eucalyptus grandis. Revista Árvore, v.36, n.6, p.1183-1190, 2012

SEVERO, E.T.D.; TOMASELLI, I.; CALONEGO, F.W.; FERREIRA, A.L.; MENDES, L.M. Effect of steam thermal treatment on the drying process of Eucalyptus dunnii variables. Cerne, v.19, n.4, p.637-645, 2013.

SKAAR, C.J. Water in wood. Syracuse: Syracuse University, 1972. 218p. 
SIAU, J.F. Flow in wood. Syracuse: Syracuse University, 1971. 245p.

SOARES, V.C.; BIANCHI, M.L.; TRUGILHO, P.F.; PEREIRA, A.J.; HÖFLER, J. Correlações entre as propriedades da madeira e do carvão vegetal de híbridos de eucalipto. Revista Árvore, v.38, n.3, p.543-549, 2014.

TIRYAKI, S.; AYDIN, A. An artificial neural network model for predicting compression strength of heat treated woods and comparison with a multiple linear regression model.

Construction and Building Materials, v.62, n.3, p.102-108, 2014a.

TIRYAKI, S.; AYDIN, A. Predicting modulus of rupture (MOR) and modulus of elasticity (MOE) of heat treated woods by artificial neural networks. Measurement, v.49, n.4, p.266-274, 2014b.
ZANUNCIO, A.J.V.; MONTEIRO, T.C.M.; LIMA, J.T.; ANDRADE, H.B.; CARVALHO, A.G. Biomass for energy use of Eucalyptus urophylla and Corymbia citriodora logs. BioResources, v.8, n.4 p.5159-5168, 2013a.

ZANUNCIO,A.J.V.; LIMA, J.T.; MONTEIRO, T.C.; CARVALHO, A.G.; TRUGILHO, P.F. Secagem de toras de Eucalyptus e Corymbia para uso energético. Scientia Forestalis, v.41, n.99, p.353-360, 2013b.

ZANUNCIO, A.J.V.; CARVALHO, A.G.C.; TRUGILHO, P.F.; MONTEIRO, T.C. Extractives and energetic properties of wood and charcoal. Revista Árvore, v.38, n.2, p.369-374, 2014a.

ZANUNCIO, A.J.V.; MOTTA, J.P.; DA SILVEIRA, T.A.; FARIAS, E.S.; TRUGILHO, P.F. Physical and colorimetric changes in Eucalyptus grandis wood after heat treatment. BioResources, v.9, n.1, p.293-302, 2014b. 